Biogeosciences Discuss., 5, 1511-1543, 2008

www.biogeosciences-discuss.net/5/1511/2008/

(C) Author(s) 2008. This work is distributed under

\title{
Incorporating changes in albedo in estimating the climate mitigation benefits of land use change projects
}

Albedo and sequestration in LULUCF projects

D. N. Bird et al.

D. N. Bird ${ }^{1}$, M. Kunda ${ }^{2}$, A. Mayer ${ }^{3}$, B. Schlamadinger ${ }^{4}$, L. Canella ${ }^{1}$, and M. Johnston ${ }^{5}$

${ }^{1}$ JOANNEUM RESEARCH, Elisabethstraße 5, 8010, Graz, Austria

${ }^{2}$ School of Interactive Computing, Georgia Institute of Technology, 85 Fifth Street NW, Atlanta, GA, 30308 USA

${ }^{3}$ Institute of Plant Sciences, University of Graz, Schubertstraße 51, 8010 Graz, Austria

${ }^{4}$ TerraCarbon LLC, Dr. Eckenerstraße 21b, 8043 Graz, Austria

${ }^{5}$ Saskatchewan Research Council, 125-15 Innovation Blvd., Saskatoon, Saskatchewan S7N 2X8, Canada

Title Page

Abstract Introduction

Conclusions

Tables References Figures

14

4

Back Close

Received: 12 February 2008 - Accepted: 10 March 2008 - Published: 8 April 2008

Correspondence to: D. N. Bird (neil.bird@joanneum.at)

Published by Copernicus Publications on behalf of the European Geosciences Union.

Interactive Discussion 


\section{Abstract}

Some climate scientists are questioning whether the practice of converting of nonforest lands to forest land (afforestation or reforestation) is an effective climate change mitigation option. The discussion focuses particularly on areas where the new forest is 5 primarily coniferous and there is significant amount of snow since the increased climate forcing due to the change in albedo may counteract the decreased climate forcing due to carbon dioxide removal.

In this paper, we develop a stand-based model that combines changes in surface albedo, solar radiation, latitude, cloud cover and carbon sequestration. As well, we develop a procedure to convert carbon stock changes to equivalent climatic forcing or climatic forcing to equivalent carbon stock changes. Using the model, we investigate the sensitivity of combined affects of changes in surface albedo and carbon stock changes to model parameters. The model is sensitive to amount of cloud, atmospheric absorption, timing of canopy closure, carbon sequestration rate among other factors.

15 The sensitivity of the model is investigated at one Canadian site, and then the model is tested at numerous sites across Canada.

In general, we find that the change in albedo reduces the carbon sequestration benefits by approximately $30 \%$ over 100 years, but this is not drastic enough to suggest that one should not use afforestation or reforestation as a climate change mitigation option. cloud in winter. As well, variations in sequestration rate seem to be counterbalanced by the amount and timing of canopy closure.

We close by speculating that the effects of albedo may also be significant in locations at lower latitudes, where there are less clouds, and where there are extended dry dark forests or other vegetation such as biofuels replace the grasses, the change in carbon stocks may not compensate for the darkening of the surface.

BGD

$5,1511-1543,2008$

\section{Albedo and sequestration in LULUCF projects}

D. N. Bird et al.

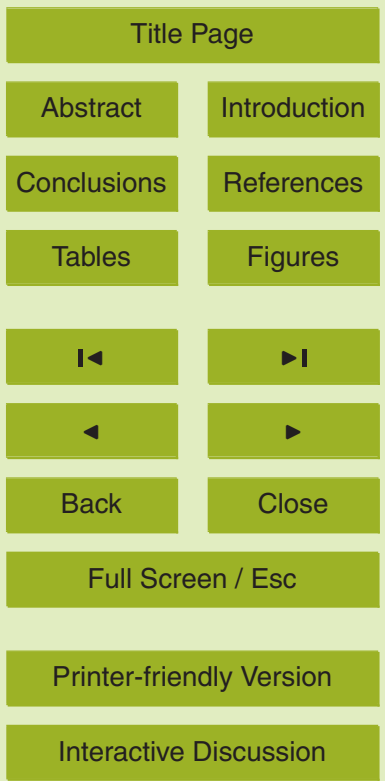




\section{Introduction}

The removal and storage of carbon dioxide from the atmosphere by photosynthesis (sequestration) as trees grow is considered a climate change mitigating activity. For this reason, there has been interest in converting non-forest lands into forests (afforestation

5 or reforestation).

This practice has been questioned by some authors since there is often an associated change in surface albedo as a result of the land-use change. For example, Betts (2000) found that the change in surface albedo by the planting of coniferous forests in areas with snow can contribute significantly to the radiative forcing. Brovkin

et al. (1999) found that cooling due to albedo change from deforestation was of the same order of magnitude as increased radiative forcing from $\mathrm{CO}_{2}$ and solar irradiation. Bala et al. (2008) found that a global-scale deforestation event could have a net cooling influence on the Earth's climate.

Matthews et al. (2003) on the other hand suggest that the issue needs to be re15 visited with more realistic scenarios of transient land cover change. In a subsequent paper, Matthews et al. (2004) suggest that carbon emissions from land cover changes (deforestation) tend to exceed the cooling that results from change in surface albedo.

In this paper, we model the changes in radiative forcing due to changes in top-ofatmosphere albedo and carbon stocks over time due to a change in land-use from grasslands to forest in various locations and forest types in Canada. We present the combined impacts in terms of radiative forcing and equivalent changes in $\mathrm{CO}_{2}$.

\section{The Model}

\subsection{Carbon}

To model the changes in carbon stocks over time we use the stand level carbon model, 25 GORCAM (Schlamadinger and Marland, 1996). This is a simple model that tracks the
BGD

$5,1511-1543,2008$

\section{Albedo and sequestration in LULUCF projects}

D. N. Bird et al.

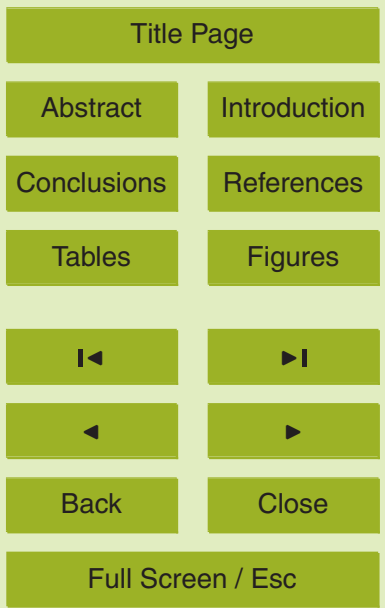

Printer-friendly Version

Interactive Discussion 
flow of carbon from living above and below ground biomass to the dead wood, litter and soil pools. The model assumes that the living above ground biomass is driven by local growth curves or yield tables; the below ground living biomass is a function of the above ground biomass; and that annual non-living input is a fraction of the living 5 biomass. The non-living biomass decays exponentially with decay rates based on temperature, rainfall and material (Moore et al., 1999; Trofymow et al., 2002). Some of the decaying material enters the soil pool, which also decays exponentially.

The carbon model, GORCAM, is similar to other carbon models CO2FIX and CBM3 in its approach, but is a simpler version that reduces the amount of parameters required 10 for use in areas of sparse data.

\subsection{Surface albedo}

Albedo is a very complex function of surface and radiation characteristics, including land cover type, specifics of the vegetation, snow cover, soil moisture, incident angle, and wavelength (Henderson-Sellers and Wilson, 1983). Representations of albedo range from relatively simple functions of land cover type and snow (Henderson-Sellers and Wilson, 1983) to sophisticated models that include vegetation geometry and distribution and also multiple scattering and angle effects (Ni and Woodcock 1999, Yin, 1998).

In general, the major trends observed with surface albedo are that 1) albedo increases with snow cover, which is more reflective than foliage or soil, and that 2) forests, especially coniferous ones, have lower albedo than grass or crop covers, due to their denser canopies that trap more of the incident radiation (Robinson and Kukla, 1984; Sharratt, 1998)

For our model, we use Yin's model (Yin 1998) with modifications for variables that depend on site characteristics. Yin's model starts with a base albedo that is dependent on: stem cover; canopy cover; and life span and size of canopy leaves. The base albedo is then multiplied by factors that result from changes in: vegetation height; relative leaf age; seasonal biological stress; drought; and optical air mass. Finally

BGD

$5,1511-1543,2008$

\section{Albedo and sequestration in LULUCF projects}

D. N. Bird et al.

Title Page

Abstract

Introduction

Conclusions

Tables

References

Figures

14

$\rightarrow$

4

Back

Close

Full Screen / Esc

Printer-friendly Version

Interactive Discussion 
the modified base albedo is blended with the snow albedo where the blending factor depends on snow presence, canopy closure and height.

We use a simplified form of Yin's full model that does not include variations in the seasonal biological stress or optical air mass. As well we base stem cover closure and 5 height are simple function of tree biomass. Therefore:

$W_{i}=\left(\frac{B_{i}\left[\mathrm{tha}^{-1}\right]}{B_{\text {closure }}\left[\mathrm{tha}^{-1}\right]}\right)^{0.5} \operatorname{for} B \leq B_{\text {closure }}$

And

$H_{i}[m]=\frac{H_{\max }[m] B_{i}\left[\mathrm{tha}^{-1}\right]}{B_{\max }\left[\mathrm{tha}^{-1}\right]}$

Where $W_{i}$ is the stem cover in year $i, B_{i}$ is the tree biomass in year $i, B_{\text {closure }}$ is the tree biomass when closure is reached, $H_{i}$ is the height of trees in year $i, H_{\max }$ is the maximum tree height. As well, Yin's snow factor is calculated using a snow presence as the fraction of the month that the site has snow depths greater than $5 \mathrm{~cm}$. The surface albedo from January-May for a coniferous forest in Prince George, Canada as a function of age is shown in Fig. 1.

\subsection{Top-of-atmosphere albedo}

The climate forcing effect of changes in surface albedo is masked by clouds. As a result, the model must also include annual variations in cloud cover. We propose the following simplified model for the energy interaction of the surface with a cloud layer in between (Fig. 2).

The incident radiation, $R$, is partially reflected by the cloud layer by the amount $\alpha_{C}$, partially absorbed by the amount $A_{b}$ and an amount, $\tau_{c}$ is transmitted.

BGD

$5,1511-1543,2008$

\section{Albedo and sequestration in LULUCF projects}

D. N. Bird et al.

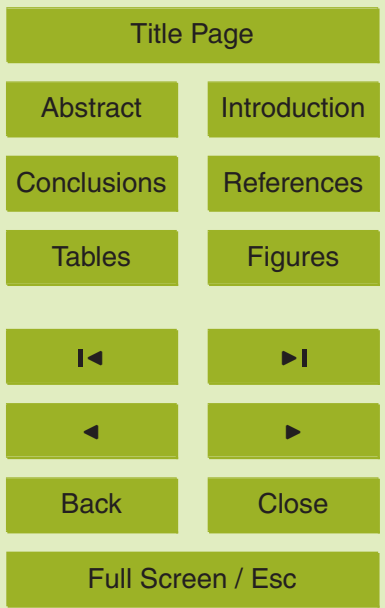

Printer-friendly Version

Interactive Discussion 
At the surface, the transmitted radiation is partially reflected by the amount $\alpha_{c}$. This value is the albedo of the vegetation.

On the return path, the energy from the surface is partially reflected back towards the surface by the clouds and partially transmitted by the same amounts as from above $5\left(\alpha_{c}, \tau_{c}\right)$. The re-reflected energy is reflected off the vegetation again and so on.

In general, the transmission and reflection coefficients will be frequency dependent, but for the remaining of the paper we will not include a frequency variable for ease of presentation.

The total reflected energy, $E$, is the sum of all returning energy:

$10 E=R\left[\alpha_{c}+\tau_{c} \alpha_{v} \tau_{c}+\tau_{c} \alpha_{v} \alpha_{c} \alpha_{v} \tau_{c}+\tau_{c} \alpha_{v} \alpha_{C} \alpha_{v} \alpha_{c} \alpha_{v} \tau_{c}+\ldots\right]$

Collecting terms:

$E=R\left[\alpha_{c}+\frac{\tau_{c}^{2}}{\alpha_{c}}\left(\alpha_{v} \alpha_{c}+\alpha_{v}^{2} \alpha_{c}^{2}+\alpha_{v}^{3} \alpha_{c}^{3}+\ldots\right)\right]$

\section{Since}$$
\frac{1}{1-x}=1+x+x^{2}+x^{3}+\ldots+x^{n} \text { for }|x|<1
$$

The reflected energy becomes:

$E=R\left[\alpha_{c}+\frac{\tau_{c}^{2} \alpha_{v}}{1-\alpha_{c} \alpha_{v}}\right]$

And the effective albedo is

$\alpha_{\text {eff }}=\frac{E}{R}=\left[\alpha_{c}+\frac{\tau_{c}^{2} \alpha_{v}}{1-\alpha_{c} \alpha_{v}}\right]$

If we assume there is absorption by the atmosphere then $\tau_{c}=1-\alpha_{c}-A_{b}$.

BGD

5, 1511-1543, 2008

Albedo and sequestration in LULUCF projects

D. N. Bird et al.

Title Page

Abstract

Introduction

Conclusions

References

Tables

Figures

14

$\rightarrow$

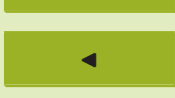

Back

Close

Full Screen / Esc

Printer-friendly Version

Interactive Discussion 
The percentage of possible sunshine is a readily available measurement (for example; IWMI 2007). If we assume that cloudiness is related to the lack of sunshine and also that the reflectivity is proportional to cloudiness then:

$$
\alpha_{c}=k_{c}(1-S)
$$

5 Where $S=$ percentage of possible sunshine and $k_{c}$ is a factor that controls the opacity or reflectivity of the clouds such that

$0 \leq k_{c} \leq \frac{\left(1-A_{b}\right)}{(1-S)}$

If $k_{c}=0$ then the clouds are transparent. Substituting into Eq. (6):

$\alpha_{\text {eff }}=\frac{k_{c}(1-S)\left(1-2 \alpha_{v}\left(1-A_{b}\right)\right)+\alpha_{v}\left(1-A_{b}\right)^{2}}{1-k_{c} \alpha_{v}(1-S)}$

10 For typical values of sunnyness, $S \sim 0.4, A_{b} \sim 0.2$ (Valero et al, 2000) and $\tau_{c} \sim 0.52$ (Haigh, 2007), then $k_{c} \sim 0.5$. Based on a least squares best-fit of the model to surface radiation measurements at eights sites across the United States, we find values of $A_{b}$ and $k_{c}$ of 0.25 and 0.65 , respectively.

It is generally known that $A_{b}$ varies with elevation, solar angle, air pollution, water vapour and dust particles. These factors tend to increase absorption and scattering by the atmosphere, thus decreasing the albedo further. For this discussion, we will assume that it is constant and investigate the sensitivity of the results to this assumption.

The components of the albedo for a 75 year old Lodgepole pine stand at Prince George, British Columbia are shown in Fig. 3. The vegetation changes little during the year. With snow in January, February, March, November and December, the surface albedo (vegetation + snow) is a little higher. Finally, when the effect of clouds is added, the effective albedo is increases for all months. The increase is greatest in the winter months when Prince George receives less than $25 \%$ of possible sunshine.

\section{BGD}

5, 1511-1543, 2008

\section{Albedo and sequestration in LULUCF projects}

D. N. Bird et al.

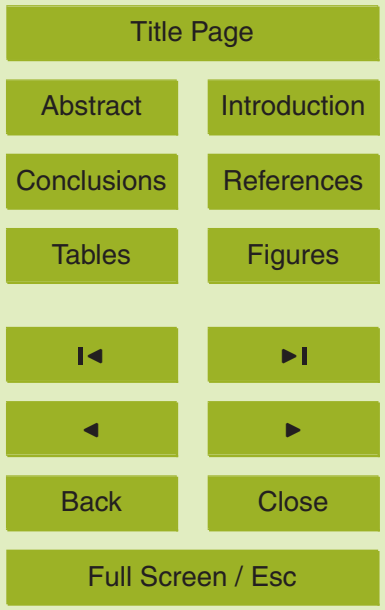

Printer-friendly Version

Interactive Discussion 
The effective albedo of grass is also shown in this figure. A grassy field has on average albedo only 0.05 higher than a forest stand. The difference in albedo is greatest (0.08) in the winter due to the presence of snow on the grassy field.

A comparison of the surface and effective albedo of a forest with age in January in 5 Prince George is given in Fig. 3.

It should be noted that Prince George has only $22 \%$ sunshine in the January (CCN, 2007).

\section{Radiative forcing}

\subsection{Change in $\mathrm{CO}_{2}$ concentration}

10 In Betts (2000), he presents the annual radiative forcing as:

$F_{\mathrm{CO}_{2}}^{\mathrm{Ann}}\left[\mathrm{Wm}^{-2}\right]=B\left[\mathrm{Wm}^{-2}\right] \ln \left(1+\frac{\Delta \mathrm{CO}_{2}[\mathrm{ppmv}]}{\mathrm{pCO}_{2, \mathrm{ref}}[\mathrm{ppmv}]}\right)$

Where, $\mathrm{pCO}_{2, \text { ref }}=\mathrm{a}$ reference partial pressure $(383 \mathrm{ppmv})$, and from Betts (2000)

$\Delta \mathrm{CO}_{2}[\mathrm{ppmv}]=\frac{\Delta \mathrm{CO}_{2}[\mathrm{~g}]}{M_{\mathrm{CO}_{2}}\left[\mathrm{gmole}^{-1}\right]}\left(\frac{M_{\mathrm{air}}\left[\mathrm{gmole}^{-1}\right]}{m_{\text {air }}[\mathrm{g}]}\right) * 1.0 \times 10^{6}[\mathrm{ppmv}]$

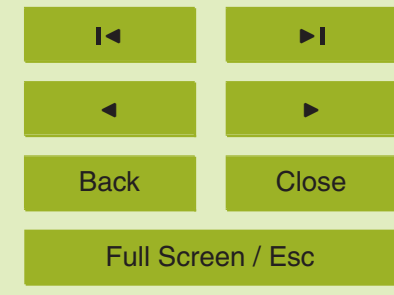

Because the volume of a mole of gas is independent of the gas constitution.

$M_{\mathrm{CO} 2}=$ molecular mass of carbon $(44.0095 \mathrm{~g} / \mathrm{mol}), M_{\text {air }}=$ molecular mass of dry air $(28.95 \mathrm{~g} / \mathrm{mol}), m_{\text {air }}=$ mass of the atmosphere $\left(5.148 \times 10^{15} \mathrm{Mg}\right)$ and $\Delta \mathrm{CO}_{2}=$ the change in $\mathrm{CO}_{2}$ (in grams) as a result of the reforestation project.

The constant, $\mathrm{B}$, is calculated as

\section{BGD}

$5,1511-1543,2008$

\section{Albedo and sequestration in LULUCF projects}

D. N. Bird et al.

Title Page

Abstract

Introduction

Conclusions

References

Tables

Figures

$B\left[\mathrm{Wm}^{-2}\right]=\frac{\Delta F_{2 X}\left[\mathrm{Wm}^{-2}\right]}{\ln (2)}$ 
Where $\Delta F_{2 X}=$ the radiative forcing per $\mathrm{CO}_{2}$ doubling $\left(3.7 \mathrm{Wm}^{-2}\right)$ (IPCC).

Combining equations:

BGD

$F_{\mathrm{CO}_{2}}^{\mathrm{Ann}}\left[\mathrm{Wm}^{-2}\right]=\frac{\Delta F_{2 X}\left[\mathrm{Wm}^{-2}\right]}{\ln (2)}$

$\ln \left(1+\frac{1.0 \times 10^{6}[\mathrm{ppmv}] \Delta \mathrm{CO}_{2}[\mathrm{~g}] M_{\text {air }}\left[\mathrm{gmole}^{-1}\right]}{\mathrm{pCO}_{2, \text { ref }}[\mathrm{ppmv}] M_{\mathrm{CO}_{2}}\left[\mathrm{gmole}^{-1}\right] 1.0 \times 10^{6} \mathrm{~m}_{\mathrm{air}}[\mathrm{Mg}]}\right)$ growth time scales. The decay of $\mathrm{CO}_{2}$ is given by:

$\Delta \mathrm{pCO}_{2}(t)=\Delta \mathrm{pCO}_{2, \text { init }}\left(a_{0}+\sum_{i=1}^{4} a_{i} e^{-t / \tau_{i}}\right)$

Where $\Delta \mathrm{pCO}_{2 \text {,init }}=$ the initial perturbation of atmospheric $\mathrm{CO}_{2}$ content and $\mathrm{a}_{i}$ and $\tau_{i}$ are decay constants (Archer et al., 1997; Maier-Reimer and Hasselmann, 1987).

Including this term and assuming making a small scale approximation to $\ln (1+x)$,

$F_{\mathrm{CO}_{2}}^{\mathrm{Ann}}(t)\left[\mathrm{Wm}^{-2}\right] \approx \frac{\Delta F_{2 X}\left[\mathrm{Wm}^{-2}\right]}{\ln (2)}$

$\left(\frac{1.0 \times 10^{6}[\mathrm{ppmv}] \Delta \mathrm{CO}_{2}[\mathrm{~g}] M_{\text {air }}\left[\mathrm{gmole}^{-1}\right]}{\mathrm{pCO}_{2, \text { ref }}[\mathrm{ppmv}] M_{\mathrm{CO}_{2}}\left[\mathrm{gmole}^{-1}\right] 1.0 \times 10^{6} \mathrm{~m}_{\mathrm{air}}[\mathrm{Mg}]}\right)\left(a_{0}+\sum_{i=1}^{4} a_{i} e^{-t / \tau_{i}}\right)$

And for a project that removes $\mathrm{CO}_{2}$ annually:

$F_{\mathrm{CO}_{2}}^{\mathrm{Ann}}(t)\left[\mathrm{Wm}^{-2}\right] \approx \frac{\Delta F_{2 X}\left[\mathrm{Wm}^{-2}\right]}{\ln (2)}$

\section{Albedo and sequestration in LULUCF projects}

D. N. Bird et al.

Title Page

5, 1511-1543, 2008

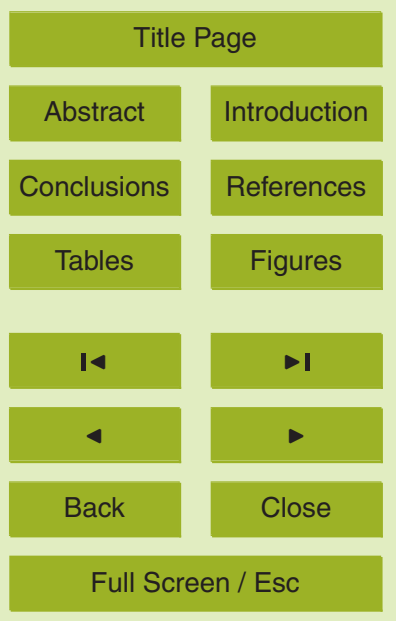

Printer-friendly Version

Interactive Discussion 
$\left(\frac{1.0 \times 10^{6}[\mathrm{ppmv}] \Delta \mathrm{CO}_{2}(t)[\mathrm{g}] M_{\mathrm{air}}\left[\mathrm{gmole}^{-1}\right]}{\mathrm{pCO}_{2, \text { ref }}[\mathrm{ppmv}] M_{\mathrm{CO}_{2}}\left[\mathrm{gmole}^{-1}\right] 1.0 \times 10^{6} m_{\mathrm{air}}[\mathrm{Mg}]}\right) \otimes \operatorname{Decay}_{\mathrm{CO}_{2}}^{\mathrm{Ann}}(t)$

Where $\otimes$ represents the convolution operation and Decay $\mathrm{CO}_{2}(t)$ is given by:

Decay $_{\mathrm{CO}_{2}}^{\mathrm{Ann}}(t)=a_{0}+\sum_{i=1}^{4} a_{i} e^{-t / \tau_{i}}$

\subsection{Change in albedo}

5 The annual change in forcing due to a change in albedo at the top of the atmosphere (TOA) as:

$F_{\alpha}^{\text {Ann }}(t)\left[\mathrm{Wm}^{-2}\right]=\frac{-R\left[\mathrm{Wm}^{-2}\right] A\left[\mathrm{~m}^{2}\right] \Delta \alpha(t)}{A_{\text {Earth }}\left[\mathrm{m}^{2}\right]}$

$R=$ impinging radiation $A=$ area of albedo change, $A_{\text {Earth }}=$ the area of the earth $\left(5.1 \times 10^{14} \mathrm{~m}^{2}\right)$ and $\Delta \alpha$ albedo change.

This is a rather simplistic model since the albedo change and radiation both vary with season. With this consideration:

$F_{\alpha}^{\text {Ann }}(t)\left[\mathrm{Wm}^{-2}\right]=-\frac{A\left[\mathrm{~m}^{2}\right]}{12 A_{\text {Earth }}\left[\mathrm{m}^{2}\right]} \sum_{m=1}^{12} R_{m}\left[\mathrm{Wm}^{-2}\right] \Delta \alpha_{m}(t)$

Where $m=$ month. It is important to note that one should be consistent. Either the radiation and albedo are both measured at the top of atmosphere (i.e. above the clouds),
BGD

$5,1511-1543,2008$

\section{Albedo and} sequestration in LULUCF projects

D. N. Bird et al.

Title Page

Abstract

Introduction

Conclusions

References

Tables

Figures

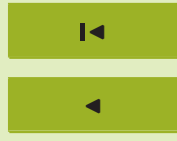

Back

Close

$F_{\alpha}^{\text {Ann }}(t)\left[\mathrm{Wm}^{-2}\right]=-\frac{A\left[\mathrm{~m}^{2}\right]}{12 A_{\text {Earth }}\left[\mathrm{m}^{2}\right]} \sum_{m=1}^{12} R_{\mathrm{TOA}, m}\left[\mathrm{Wm}^{-2}\right] \Delta \alpha_{\mathrm{eff}, \mathrm{m}}(t)$ 
Where $\Delta \alpha_{\text {eff,m }}$ is the effective albedo change taking into account cloud cover and $R_{\mathrm{TOA}, \mathrm{m}}$ is the monthly top-of-atmosphere radiation.

One can estimate $R_{\mathrm{TOA}, \mathrm{m}}$ geometrical considerations, since the Earth receives $1360 \mathrm{~W} / \mathrm{m}^{2}$ of mean annual solar radiation, but this radiation varies with latitude.

The cross sectional area at a given latitude, $\lambda$, and longitude, $\phi$, ignoring inclination of the Earth's axis is given by:

$d A=(r \cos \lambda d \lambda)(r \cos \phi d \phi \cos \lambda)$

Therefore the average radiation at given latitude is

$\bar{R}\left[\mathrm{Wm}^{-2}\right]=\frac{\int_{\frac{-\pi}{2}}^{\frac{\pi}{2}} R_{\mathrm{Ann}}\left[\mathrm{Wm}^{-2}\right] r^{2}\left[\mathrm{~m}^{2}\right](\cos \lambda)^{2} d \lambda \cos \phi d \phi}{\int_{\pi}^{\pi} r^{2}\left[\mathrm{~m}^{2}\right] \cos \lambda d \lambda d \phi}$

10 Note: the radiation integral is evaluated from only over the sunlit regions.

$\bar{R}\left[\mathrm{Wm}^{-2}\right]=\frac{R_{\mathrm{Ann}}\left[\mathrm{Wm}^{-2}\right]}{\pi} \cos \lambda$

When, $\eta$, inclination of the earth's axis of rotation of the Earth's axis is included:

$\lambda=\lambda+\eta \cos \left[\frac{(6.5-m) \pi}{6}\right] 24$

$R_{T O A, \lambda, m}\left[\mathrm{Wm}^{-2}\right]=\frac{R_{\mathrm{Ann}}\left[\mathrm{Wm}^{-2}\right]}{\pi} \cos \left(\lambda+\eta \cos \left[\frac{(6.5-m) \pi}{6}\right]\right)$

BGD

5, 1511-1543, 2008

Albedo and sequestration in LULUCF projects

D. N. Bird et al.

Title Page

Abstract

Introduction

Conclusions

References

Tables

Figures

14

I

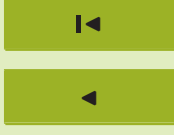

Back

Close

Full Screen / Esc

Printer-friendly Version

Interactive Discussion 


\subsection{Total forcing}

Finally, the change in forcing due to a change in land use is given by the sum of the individual forcing components above;

$F_{\text {Total }}^{\text {Ann }}(t)\left[\mathrm{W} / \mathrm{m}^{2}\right]=F_{\mathrm{CO}_{2}}^{\mathrm{Ann}}(t)\left[\mathrm{W} / \mathrm{m}^{2}\right]+F_{\alpha}^{\mathrm{Ann}}(t)\left[\mathrm{W} / \mathrm{m}^{2}\right]$

\section{$5 \quad 3.4 \quad \mathrm{CO}_{2}$ Equivalence}

Reducing radiative forcing is not the item negotiated directly as part of the UNFCCC and the Kyoto Protocol. The climate change mitigation community uses $\mathrm{CO}_{2}-$ equivalence as its indicator. Fortunately, with a little mathematical reorganization of Eq. (14), one can also express changes in radiative forcing in terms of $\mathrm{CO}_{2}$ equiva10 lence.

$\Delta \mathrm{CO}_{2} e q_{\alpha}(t)[g] \approx \frac{F_{\mathrm{CO}_{2}}^{\mathrm{Ann}}(t)\left[\mathrm{Wm}^{-2}\right] \ln (2)}{\Delta F_{2 X}\left[\mathrm{Wm}^{-2}\right]}$

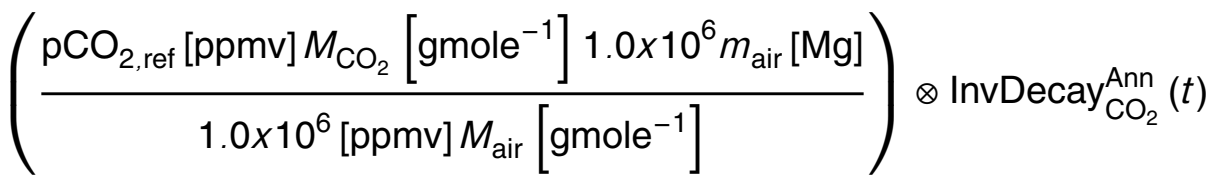

Where InvDecay ${ }_{C O_{2}}^{A n n}(t)$ is the inverse-filter of Decay ${ }_{C O_{2}}^{A n n}(t)$ so that

Decay $_{\mathrm{CO}_{2}}^{\mathrm{Ann}}(t) \otimes \operatorname{InvDecay}_{\mathrm{CO}_{2}}^{\mathrm{Ann}}(t)=1$

15 InvDecay $_{\mathrm{CO}_{2}}^{\mathrm{Ann}}(t)$ can be calculated analytically since we are modelling only changes in albedo (i.e., no change before the start of the project).

The form of Decay $\mathrm{CO}_{2}(t)$ and InvDecay $\mathrm{CO}_{2}(t)$ is shown in Fig. 5
$5,1511-1543,2008$

\section{Albedo and sequestration in LULUCF projects}

D. N. Bird et al.

Title Page

Abstract

Introduction

Conclusions

References

Tables

Figures

14

$\triangleleft$

Back

Close 


\section{An example from Prince George, Canada}

The result for a Lodgepole Pine stand (site index $=20$ ) in Prince George, B.C., Canada is shown in Fig. 6. The growth model is from TIPSY growth and yield model used by the Government of British Columbia (Ministry of Forests and Range, 2007). Cli5 matic information (\% of possible sunshine, depth of snow) is taken from Environment Canada (2006). Initially, during the first 35 years, the albedo change creates a positive forcing, but after this stage the carbon sequestration exceeds the albedo effect by at maximum a factor of 3 . As a result, the change in albedo reduces the combined forcing roughly $30 \%$. It should be noted that Prince George is a region with very cloudy

10 winters, some snow and good tree growth for Canada, so that an average stand grows with a Mean Average Increment of $3.3 \mathrm{t} /$ ha/year.

As shown in Fig. 7, the change in albedo is equivalent to an emission of roughly $39 \mathrm{t}$ $\mathrm{CO}_{2} \mathrm{e}$ during the first year. After this time, the carbon sequestration removes more $\mathrm{CO}_{2}$ than the equivalent emission caused by the change in albedo, but the later continues 15 to create an equivalent annual emission of around $2 \mathrm{t} \mathrm{CO}_{2} \mathrm{e}$.

The annual emissions are a complicated way to view the effects caused by the change in albedo. One can also display the cumulative emissions (Fig. 8). Here one clearly sees that the change in albedo causes equivalent emissions that are compensated by the sequestration after 40 years. As well, the albedo equivalent emissions reduce the sequestration by $45 \%$ after 200 years.

\subsection{Sensitivity}

We investigate the sensitivity of the cumulative emissions to atmospheric (atmospheric absorption, cloud opacity) and tree parameters (growth and canopy closure) in the model. Atmospheric parameters control the amount of energy reaching the surface the surface.

Figure 9 shows the sensitivity of the modelled results to cloud opacity. When the

\section{BGD}

$5,1511-1543,2008$

\section{Albedo and sequestration in LULUCF projects}

D. N. Bird et al.

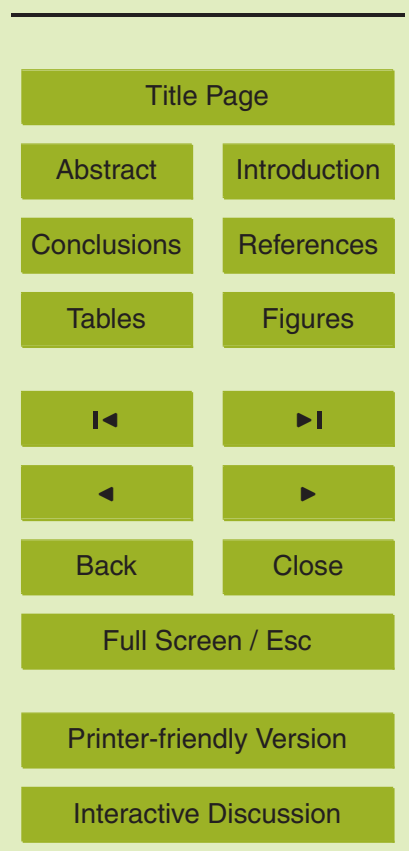


cloud are transparent, the opacity $=0$ and the change in surface albedo, because of the darker surface in winter, has a large effect. The albedo change dominates until the trees have a chance to grow rigourously. As the clouds become more reflective, the effect of the change in albedo is less and the sequestration is the dominating factor. For

5 reasonable value of cloud opacity, there is a period of small positive emissions at the onset of the reforestation, but in the long term the reforestation creates a net emission removal of approximately $800 \mathrm{t} \mathrm{CO}_{2} \mathrm{e} / \mathrm{ha}$.

Figure 10 displays the sensitivity of the modelled results to atmospheric absorption. Without absorption, the albedo change has the most impact since more energy reaches 10 the surface. As more energy is absorbed by the atmosphere, less energy reaches the surface and the benefit of carbon sequestration increases.

In Fig. 11, the sensitivity to tree dynamics are shown. Tree dynamics control, the rate of sequestration, the total amount of sequestration and the age at which canopy closure is reached. The last factor affects the surface albedo. Using the TIPSY model, which produces both biomass and canopy closure data, we have modelled a range of stand qualities ( $\mathrm{SI}=$ site index =tree height at 50 years). We see that in all cases except for the poorest stands $(\mathrm{SI}=5)$, there is a net benefit of planting trees. In the poorest stand, there are only small net emissions. This result is because at lower site indexes, the canopy closure never closes. The trees sequester less but they are also not so 20 dark.

\section{Extension to various regions of Canada}

We have used the model to evaluate the combined surface albedo with correction and carbon sequestration for various sites across Canada. The models are based on provincial growth curves for the dominant forest species, and long-term measurements

curves no not include an occurs when the annual biomass increment begins to decrease.

\section{BGD}

$5,1511-1543,2008$

\section{Albedo and sequestration in LULUCF projects}

D. N. Bird et al.

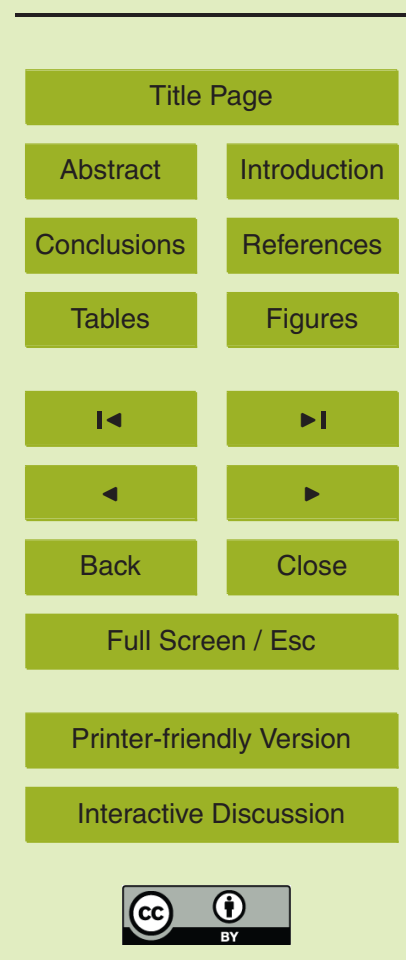


The net cumulative emissions from the modelled stands after 50 years and 100 years are shown in Fig. 12 and Fig. 13, respectively. The variation at 50 years age is caused by the variation in average growth rate at young ages. By 100 years, all stands have roughly the same cumulative net emissions $\left(-400 \mathrm{t} \mathrm{CO}_{2} \mathrm{e} / \mathrm{ha}\right)$. Sites with higher albedo 5 component, due to a sunnier climate and/or more southerly latitude, are also sites with increased sequestration.

A model of a birch forest in south eastern Quebec is also included. The site has the lowest albedo component, as one would expect since the there are no leaves in winter, but also the slowest growth over 100 years.

\section{Conclusions}

In conclusion, stand scale modelling suggests that the change in combined greenhouse gas mitigation benefit due to afforestation/reforestation projects is reduced due to the increase in albedo during months with substantial snow. This result is in agreement with other authors (Betts, 2000; Bala et al., 2008).

15 Where we differ from other authors is in the suggestion that afforestation / reforestation in areas with snow for many months has a positive radiative forcing or an equivalent greenhouse gas emission. As shown in Fig. 12 and Fig. 13 all Canadian sites analyzed showed negative net cumulative emissions as a result of an afforestation/reforestation project. The change in surface albedo is counterbalanced by two factors, sun angle and clouds. The change in albedo occurs at times of the year where the sun angle is lowest, but the dominant factor that reduces the effectiveness of the change in albedo is the inclusion of clouds. In many cases, the snowy time of the year coincides with the cloudiest time of the year. As a result, even though a snow covered field has a higher albedo than forest there is less direct sunlight that reaches the surface. It is the

\section{BGD}

$5,1511-1543,2008$

\section{Albedo and sequestration in LULUCF projects}

D. N. Bird et al.

Title Page

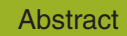

Introduction

Conclusions

Tables

References

Figures

14

$\rightarrow$

4

Back

Close

Printer-friendly Version

Interactive Discussion 


\section{Discussion}

This work is an attempt to model the climate change effects of afforestation / reforestation projects. There are still many areas of research required to properly understand the affects of changing albedo. These include:

1. An improved top of atmosphere albedo model that includes cloud cover (based on MODIS data);

2. Albedo effects due to incident angle; and

3. Timing of crown closure at maturity.

As well, this is only a partial model since it is well known that increasing tree cover

increases evapotranspiration. This will dissipate the increases in energy caused by a decrease in albedo. Modelling of these effects is beyond the scope of a locally based model. Nevertheless, a locally-based model shows that the change in albedo reduces the climate mitigation benefit of a land-use change that increases carbon sequestration. But, in the example shown, the decrease is not sufficient to suggest that afforestation / reforestation should not be considered as a climate change mitigation activity. As a corollary to this observation, it would be interesting to model the net cumulative emissions in low latitude areas with lots of sun. These areas tend to be savannas and grasslands which can have high albedo in periods of drought. We speculate that afforestation with pines or other dark vegetation and potentially irrigation of cropland in areas that were savannas and grasslands should also be investigated for their net cumulative emission profile (both sequestration and forcing due to albedo change). This has also been suggested by Field et al. (2008). For some types of vegetation such as Jatropha, the darkening of the land surface may not be compensated by the increases in sequestration.
BGD

5, 1511-1543, 2008

\section{Albedo and sequestration in LULUCF projects}

D. N. Bird et al.

Title Page

Abstract

Introduction

Conclusions

Tables

References

Figures

14

$\rightarrow$

4

Back

Close

Full Screen / Esc

Printer-friendly Version

Interactive Discussion gov/), Europe Aid-ENCOFOR (http://www.joanneum.at/encofor/), Europe Aid-RE-impact (http: 
//www.ceg.ncl.ac.uk/reimpact/index.htm), CarboEurope IP (http://www.carboeurope.org/) and GCEP (http://www.atmos.anl.gov/GCEP/). I would also like to thank G. Marland for his comments and insights during the research and preparation of this manuscript.

\section{BGD}

$5,1511-1543,2008$

\section{Albedo and sequestration in LULUCF projects}

D. N. Bird et al.

\section{Title Page}

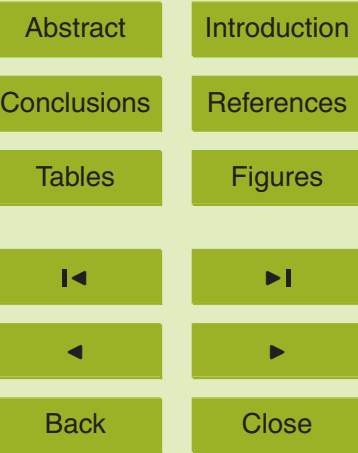

Full Screen / Esc

Printer-friendly Version

Interactive Discussion 


\section{References}

Archer, D., Kheshgi, H., and Maier-Reimer, E. Multiple timescales for neutralization of fossil fuel $\mathrm{CO}_{2}$, Geophys. Res. Lett., 24, 405-408, 1997.

Bala, G., Caldeira, K., Wickett, M., Phillips, T. J., Lobell, D. B., Delire, C., and Mirin, A.: Com5 bined Climate and Carbon-Cycle Effects of Large-Scale Deforestation, PNAS, PNAS 104, 6550-6555, 2008.

Betts, R. A.: Offset of the potential carbon sink from boreal forestation by decreases in surface albedo, Nature, 408, 187-190, 2000.

Bourque, C., Daugharty, D., Dickison, R., and Arp, P.: Changes in Albedo of a Northern Hardwood Forest Following Clearcutting, Forest Sci., 41, 268-277, 1995.

Brovkin, V., Ganopolski A., Claussen M., Kubatzki, C., and Petoukhov, V.: Modelling climate response to historical land cover change, Global Ecol. Biogeogr., 8, 509-517, 1999.

Environment: CanadaCanadian Climate Normals or Averages 1971-2000, http://www.climate. weatheroffice.ec.gc.ca/climate_normals/index_e.html, 2006.

15 Field, C., Campbell, J., and Lobell, D.: Biomass energy: the scale of the potential resource, Tree, 895, Trends Ecol. Evol., 23, 65-72, 2008.

Freedman, B. and Keith, T.: Planting trees for carbon credits: a discussion of the issues, feasibility, and environmental benefits, Tree Canada Foundation, 1995.

Henderson-Sellers, A. and Wilson, M. F.: Albedo Observations of the Earth's Surface for Climate Research, Phil. Trans. Roy. Soc. of London, 309/1508, 285-294, 1983.

Intergovernmental Panel on Climate Change (IPCC): Land use, Land-use Change and Forestry, Cambridge University Press, 377 pp., 2000.

International Water Management Institute (IWMI) World Water \& Climate Atlas, http://www. iwmi.cgiar.org/WAtlas/atlas.htm, 2007.

25 Kigomo, B. N.: Observation on the growth rate of Vitex kiniensis Turril (Meru oak) in plantation, E. Afr. Agric. For. J., 47, 32-37, 1981.

Kimball, J. W.: The Energy Relationships in Cellular Respiration and Photosynthesis: the Balance Sheet. Kimball's Biology Pages, http://users.rcn.com/jkimball.ma.ultranet/ BiologyPages/B/BalanceSheet.html, 2004.

30 Maier-Reimer, E. and Hasselmann, K.: Transport and storage of $\mathrm{CO}_{2}$ in the ocean-an inorganic ocean-circulation carbon cycle model, Clim. Dynam., 2, 63-90, 1987.

Matthews, H. D., Weaver, A. J., Eby, M., and Meissner, K. J.: Radiative forcing of climate by
BGD

$5,1511-1543,2008$

\section{Albedo and sequestration in LULUCF projects}

D. N. Bird et al.

Title Page

Abstract

Introduction

Conclusions

References

Tables

Figures

14

$\rightarrow 1$

4

Back

Close

Full Screen / Esc

Printer-friendly Version

Interactive Discussion 
historical land cover change, Geophys. Res. Lett., 30, 2, 1055, 2004.

Matthews, H. D., Weaver, A. J., Meissner, K. J., Gillett, N. P., and Eby, M.: Natural and anthropogenic climate change: incorporating historical land cover change, vegetation dynamics and the global carbon cycle, Clim. Dynam., 22, 461-479. 2004.

5 Moore, T. R., Trofymow, J. A., Taylor, B., Prescott, C., Camire, C., Duschene, L., Fyles, J., Kozak, L., Kranabetter, M., Morrison, I., Siltanen, M., Smith, S., Titus, B., Visser, S., Wein, R., Zoltai, S.: Litter decomposition rates in Canadian forests, Glob. Change Biol., 5, 1, 7582,1999.

Ministry of Forests and Range: TIPSY, Government of British Columbia, http://www.for.gov.bc. ca/hre/gymodels/tipsy/, 2007.

Nabuurs, G. J, Ravindranath, N. H., Paustian, K., Freibauer, A., Hohenstein, W., and Makundi, W.: LUCF sector good practice guidance, in: Good Practice Guidance for Land Use, LandUse Change and Forestry, edited by: Penman, J., Gytarsky, M., Hiraishi, T., Krug, T., Kruger, D., Pipatti, R., Buendia, L., Miwa, K., Ngara, T., Tanabe, K., and Wagner, F., Published by 15 the Institute for Global Environmental Strategies (IGES), Japan, for the IPCC, 2003.

Ni, W. and Woodcock, C. E.: Surface Albedo of Boreal Conifer Forests: Modeling and Measurements, Geoscience and Remote Sensing Symposium, 1999. IGARSS '99 Proceedings, IEEE 1999.

Robinson, D. A. and Kukla, G. J.: Anthropogenic Increase Of Winter Surface Albedo, Catena, 12, 215-225, 1985.

Schlamadinger, B. and Marland, G.: The Role of Forest and Bioenergy Strategies in the Global Carbon Cycle, Biomass and Bioenergy, 10, 275-300, 1996.

Sharratt, B. S.: Radiative exchange, near-surface temperature and soil water of forest and cropland in interior Alaska, Agr. Forest Meteorol., 89, 269-280, 1998.

Trofymow, J.A., Moore, T. R., Titus, B., Prescott, C., Morrison, I., Siltanen, M., Smith, S., Fyles, J., Wein, R., Camire, C. L., Duschene, L., Kozak, M. Kranabetter, M., Visser, S.: Rates of litter decomposition over six years in Canadian forests: Influence of litter quality and climate, Can. Jour. For. Res., 32, 789-804, 2002.

Yin, X.: The Albedo of Vegetated Land Surfaces: Systems Analysis and Mathematical Model30 ing, Theor. Appl. Climatol, 60, 121-140, 1998.

Zomer, R. J., Trabucco, A., van Straaten, O., and Bossio, D. A.: Carbon, land and water: A global analysis of the hydrologic dimensions of climate change mitigation through afforestation/reforestation, Colombo, Sri Lanka, International Water Management Institute, 44 pp.

BGD

$5,1511-1543,2008$

D. N. Bird et al.

Title Page

Abstract

Introduction

Conclusions

References

Tables

Figures

14

$\rightarrow$

4

Back

Close

Full Screen / Esc

Printer-friendly Version

Interactive Discussion 
(IWMI Research Report 101), 2006.

Haigh, J.: The Sun and the Earth's Climate, Max-Planck-Gesellschaft, http://solarphysics. livingreviews.org/open?pubNo=Irsp-2007-2|\&page=articlesu4.html, Access 06 December 2007.

5 Valero, F. P. J., Minnis, P., Pope, S. K., Bucholtz, A., Bush, B. C., Doelling, D. R., Smith Jr., W. L., and Dong, X.: Absorption of solar radiation by the atmosphere as determined using satellite, aircraft, and surface data during the Atmospheric Radiation Measurement Enhanced Shortwave Experiment (ARESE), J. Geophys. Res., 105, D4, 4743-4758, 2000.

\section{BGD}

$5,1511-1543,2008$

\section{Albedo and sequestration in LULUCF projects}

D. N. Bird et al.

\section{Title Page}

Abstract Introduction

Conclusions References

Tables Figures

14

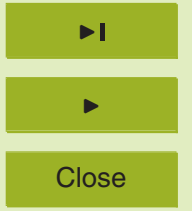

Back

\section{Full Screen / Esc}

Printer-friendly Version 
BGD

$5,1511-1543,2008$

Surface Albedo

Prince George

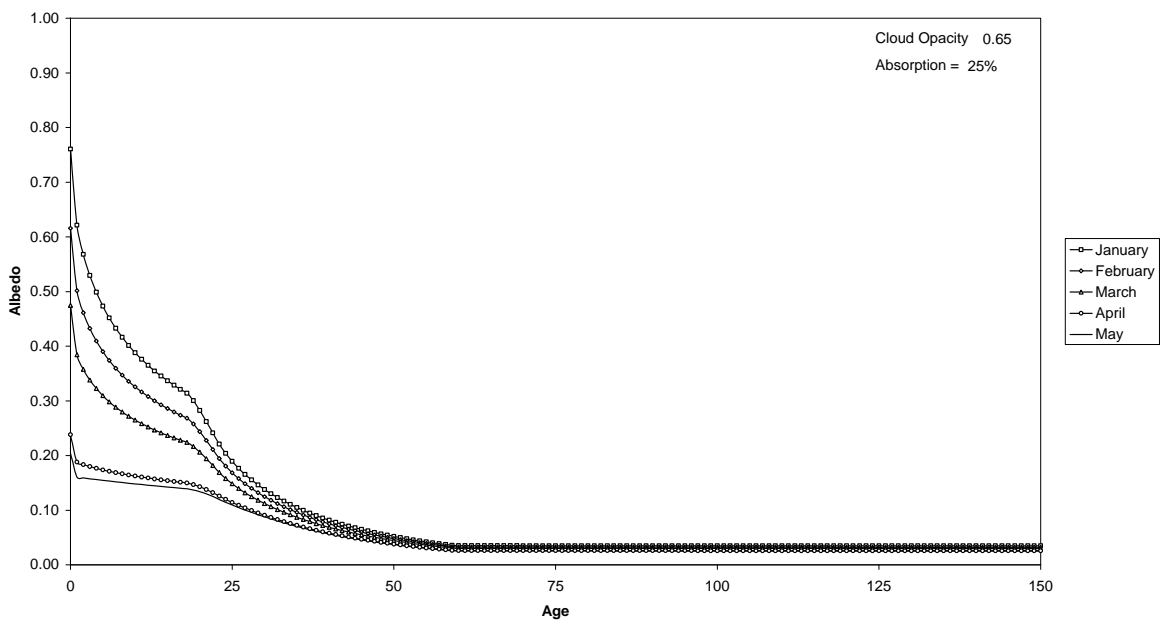

Fig. 1. Surface albedo by month and age-Prince George, Canada. Notes: The change in slope of the albedo curves at 20 years is caused by a change in growth rate of the trees as predicted by the yield tables. We have assumed a constant annual biomass increment to 20 years age.

\section{Albedo and sequestration in LULUCF projects}

D. N. Bird et al.

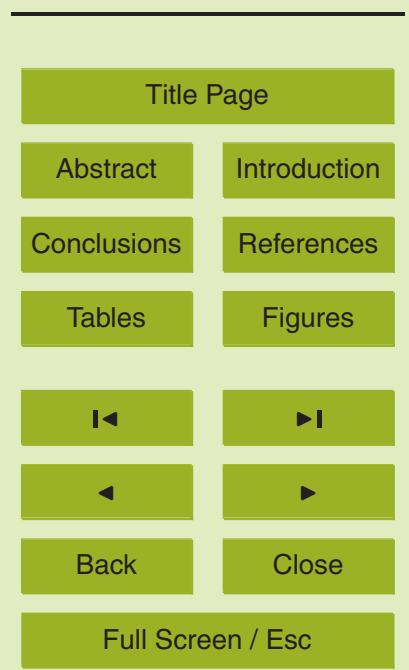

Printer-friendly Version

Interactive Discussion 
BGD

5, 1511-1543, 2008

\section{Albedo and} sequestration in LULUCF projects

D. N. Bird et al.

Title Page

Abstract

Introduction

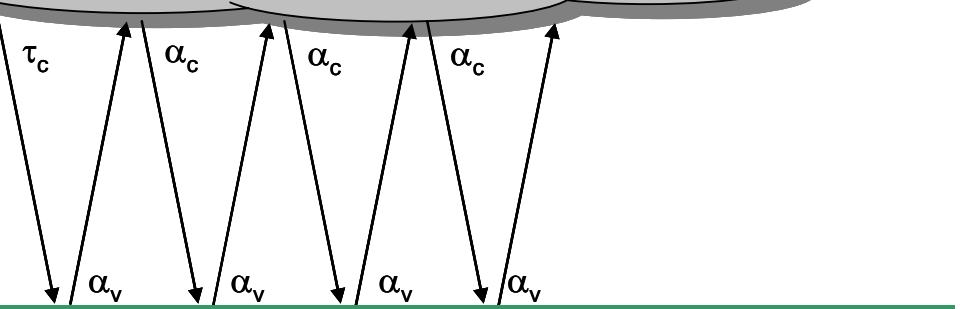

Conclusions

References

Tables

Figures

14

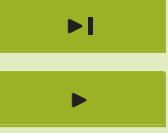

Back

Close

\section{Full Screen / Esc}

Printer-friendly Version

Interactive Discussion 
BGD

$5,1511-1543,2008$

Prince George, Lodgepole Pine 75 years

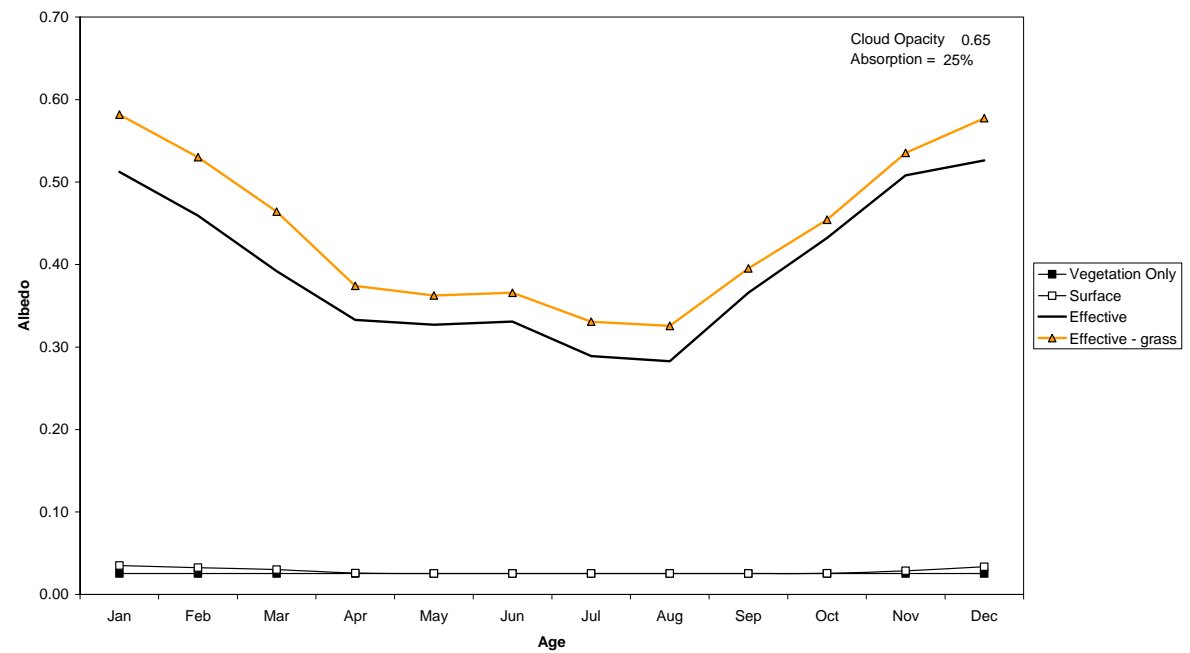

Fig. 3. Components of albedo-75 year old Lodgepole Pine Stand $(\mathrm{Si}=20)$, Prince George, B.C., Canada.

\section{Albedo and sequestration in LULUCF projects}

D. N. Bird et al.

Title Page

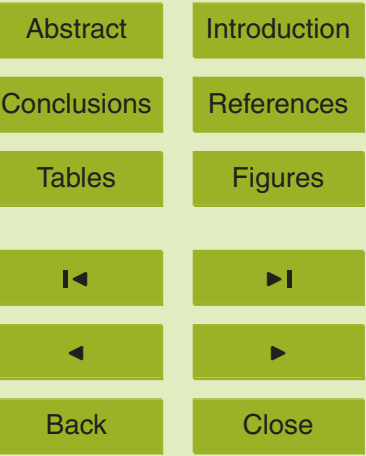

Full Screen / Esc

Printer-friendly Version

Interactive Discussion 
BGD

$5,1511-1543,2008$

January, Lodgepole Pine (SI=20), Prince George

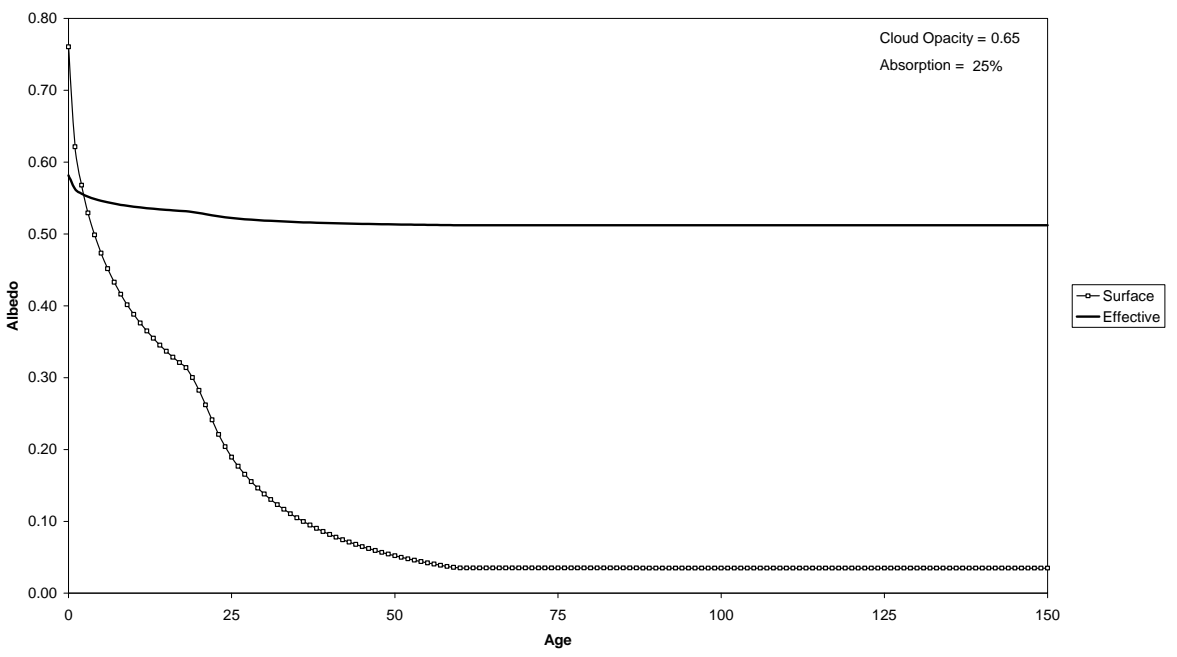

Fig. 4. A comparison of surface and effective albedo with age-January, Prince George , B.C., Canada.

\section{Albedo and sequestration in LULUCF projects}

D. N. Bird et al.

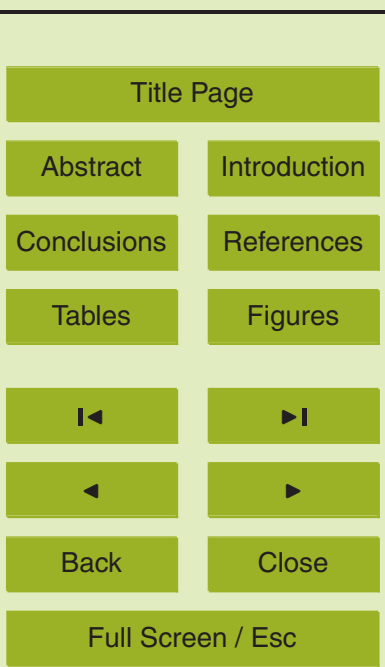

Printer-friendly Version

Interactive Discussion 
BGD

$5,1511-1543,2008$

\section{Albedo and sequestration in LULUCF projects}

D. N. Bird et al.

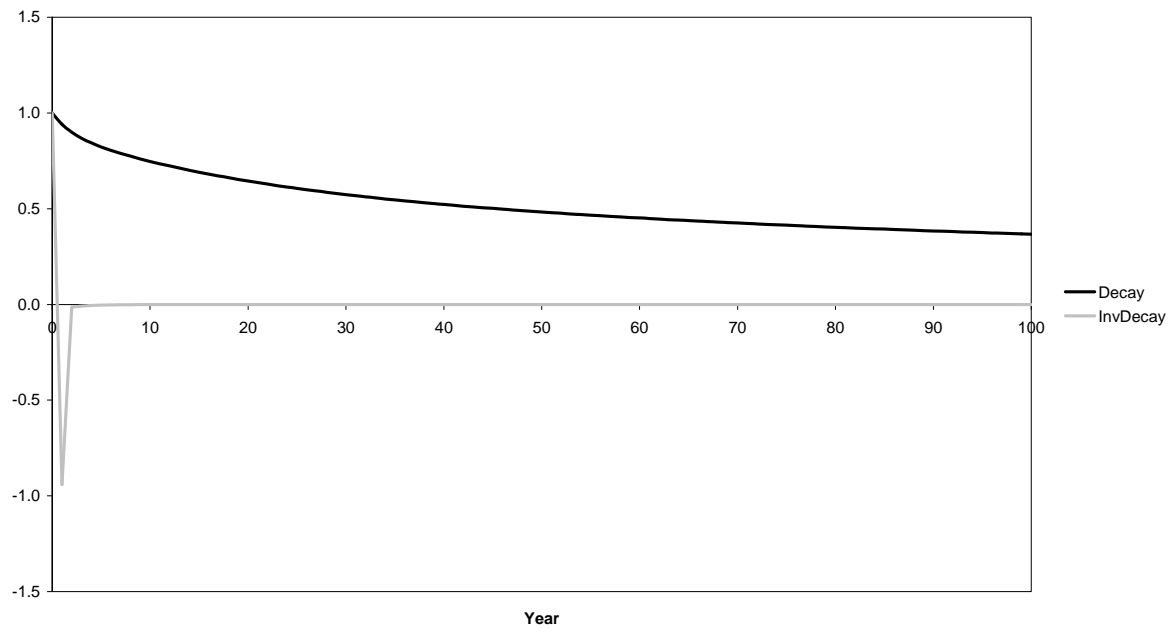

Fig. 5. The $\mathrm{CO}_{2}$ decay and inverse operators.

Interactive Discussion 
BGD

$5,1511-1543,2008$

\section{Albedo and \\ sequestration in \\ LULUCF projects}

Climatic Forcing

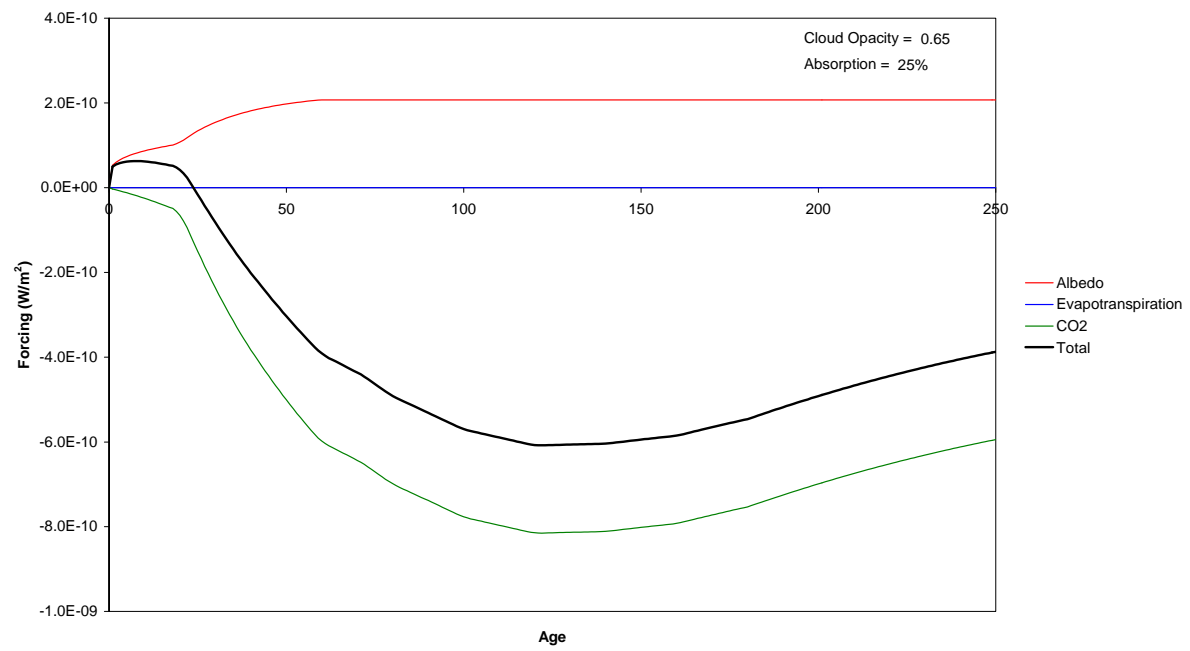

Fig. 6. Climatic forcing-Lodgepole Pine stand $(\mathrm{SI}=20)$, Prince George, B.C., Canada.
D. N. Bird et al.

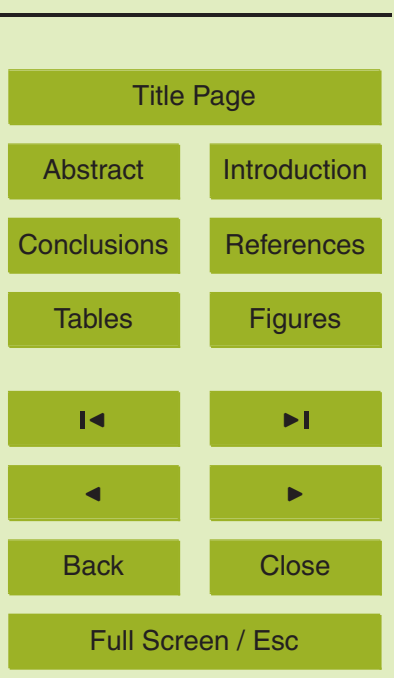

Printer-friendly Version

Interactive Discussion 
BGD

$5,1511-1543,2008$

Net Emissions

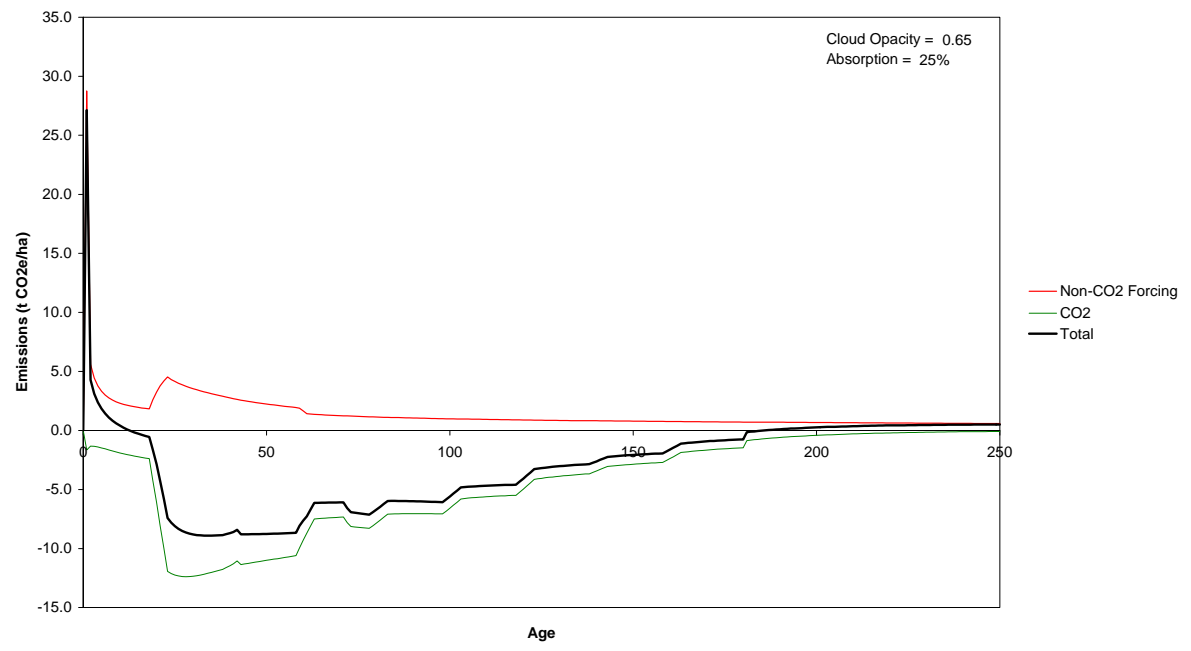

Fig. 7. Net emissions including $\mathrm{CO}_{2} \mathrm{e}$ from albedo change-Lodgepole Pine stand $(\mathrm{SI}=20)$, Prince George, B.C., Canada.

\section{Albedo and sequestration in LULUCF projects}

D. N. Bird et al.

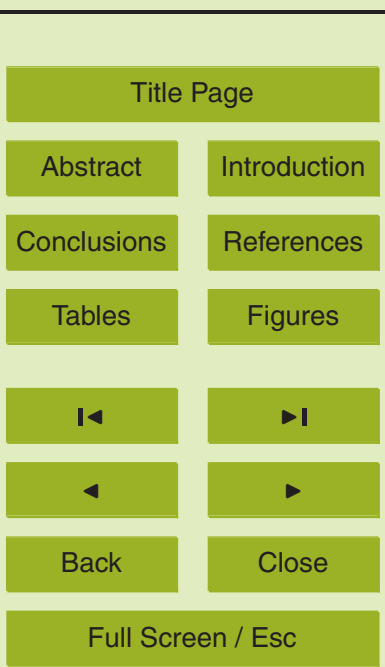

Printer-friendly Version

Interactive Discussion 
BGD

$5,1511-1543,2008$

\section{Albedo and sequestration in LULUCF projects}

Cumulative Emissions

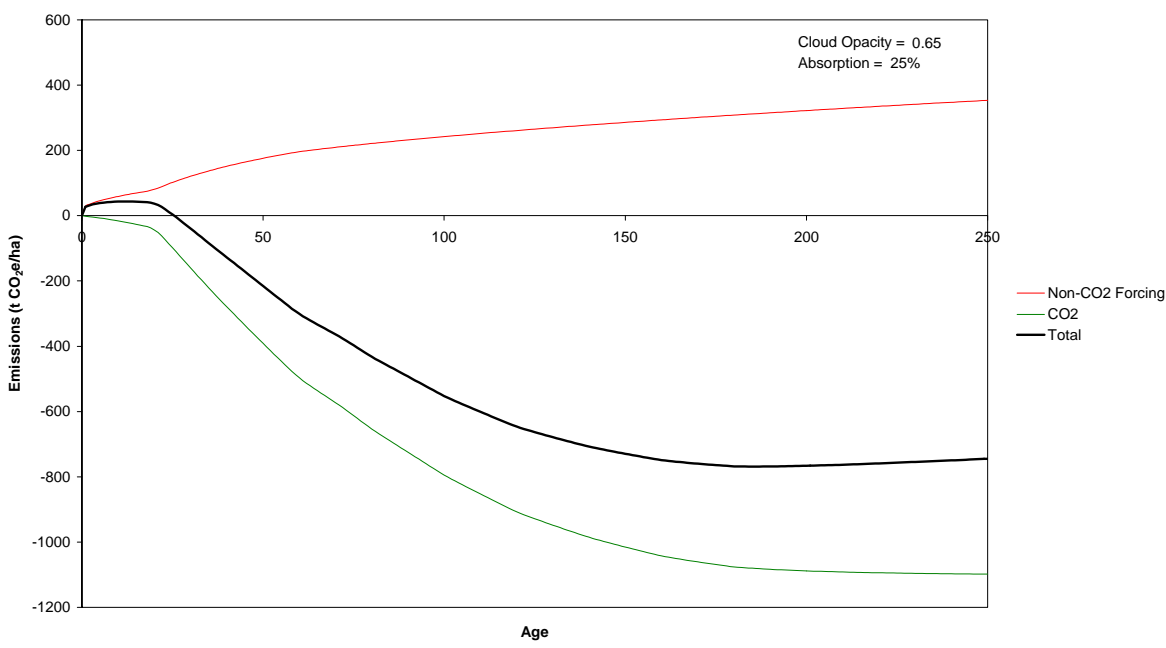

Fig. 8. Cumulative net emissions including $\mathrm{CO}_{2} \mathrm{e}$ from albedo change-Lodgepole Pine stand $(\mathrm{SI}=20)$, Prince George, B.C., Canada.
D. N. Bird et al.

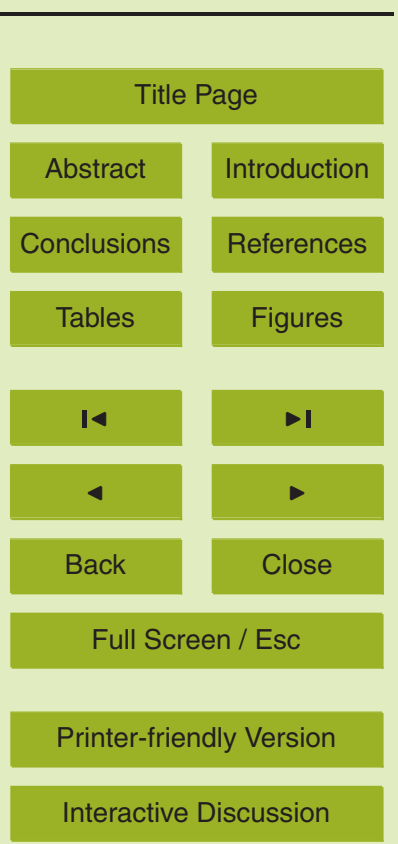


BGD

$5,1511-1543,2008$

Cumulative Emissions

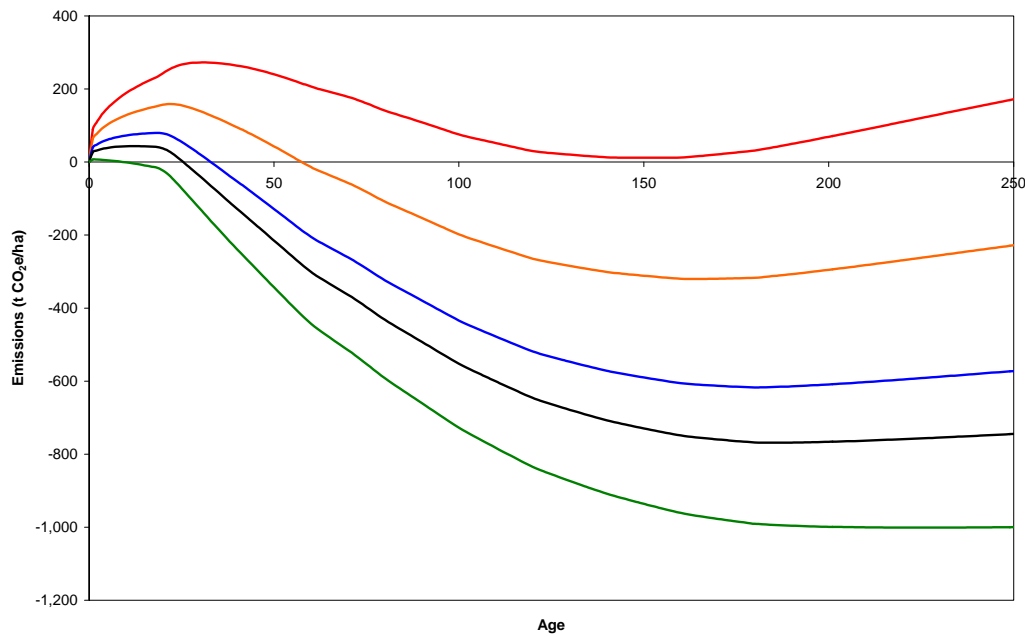

Fig. 9. Sensitivity of cloud opacity on cumulated net emissions-Lodgepole Pine stand $(\mathrm{SI}=20)$, Prince George, B.C., Canada.
一 Opacity $=0.00$

—opacity $=0.25$

- Opacity $=0.65$

-Opacity $=0.65$

on

\section{Albedo and} sequestration in LULUCF projects

D. N. Bird et al.

Title Page

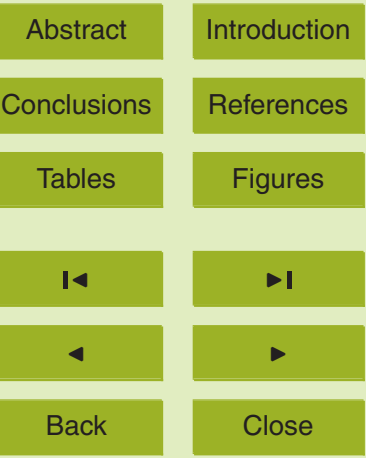

Full Screen / Esc

Printer-friendly Version

Interactive Discussion 
BGD

$5,1511-1543,2008$

Cumulative Emissions

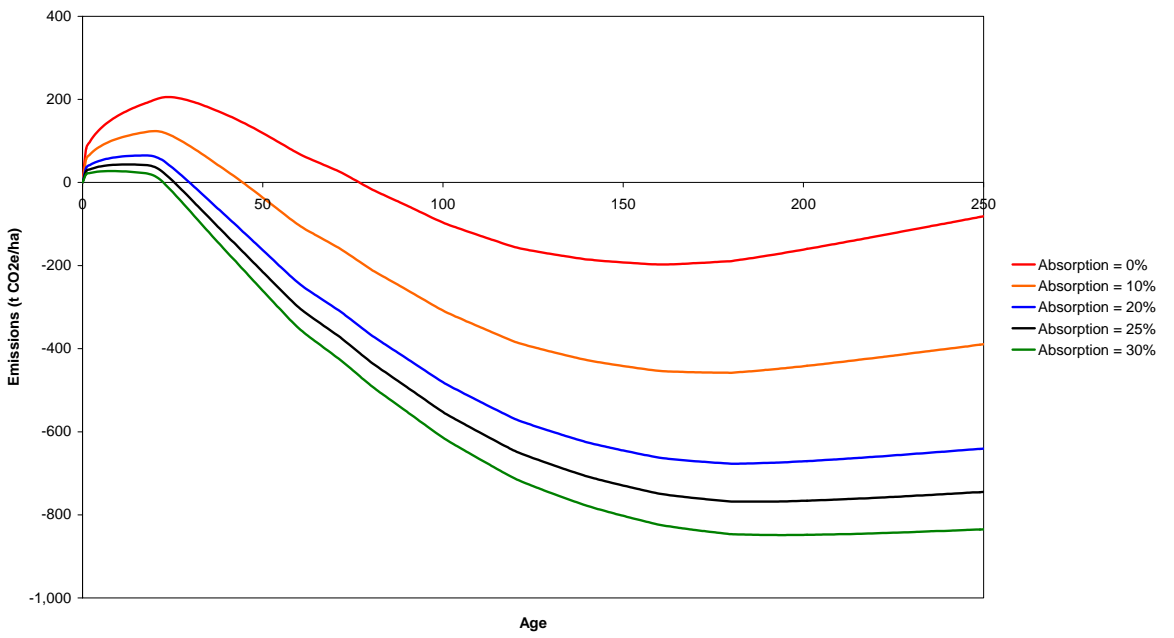

Fig. 10. Sensitivity of absorption on cumulated net emissions-Lodgepole Pine stand $(\mathrm{SI}=20)$, Prince George, B.C., Canada.

\section{Albedo and sequestration in LULUCF projects}

D. N. Bird et al.

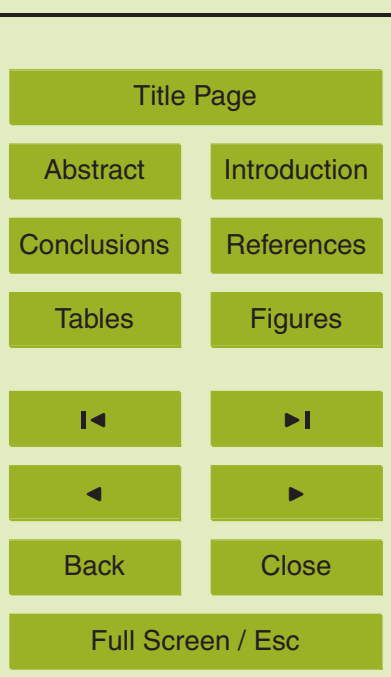

Printer-friendly Version

Interactive Discussion 
BGD

$5,1511-1543,2008$

Cumulative Emissions

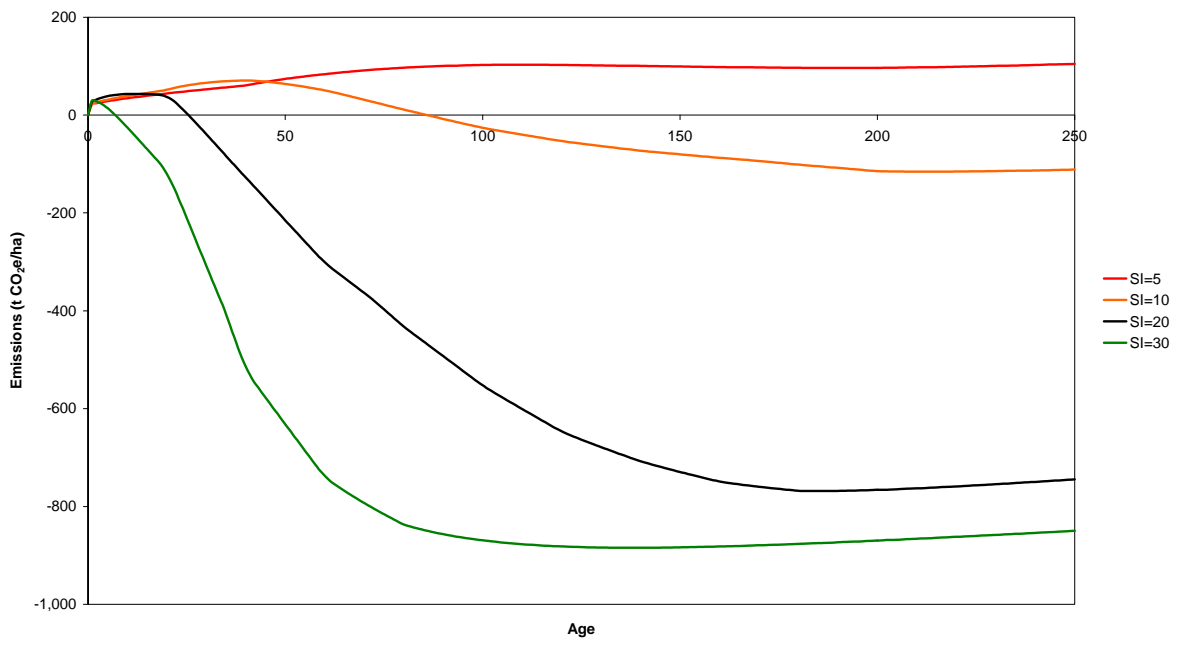

Fig. 11. Sensitivity of tree dynamics on cumulated net emissions-Lodgepole Pine stand (opacity $=0.65$, absorption $=25 \%$ ), Prince George, B.C., Canada

\section{Albedo and sequestration in LULUCF projects}

D. N. Bird et al.

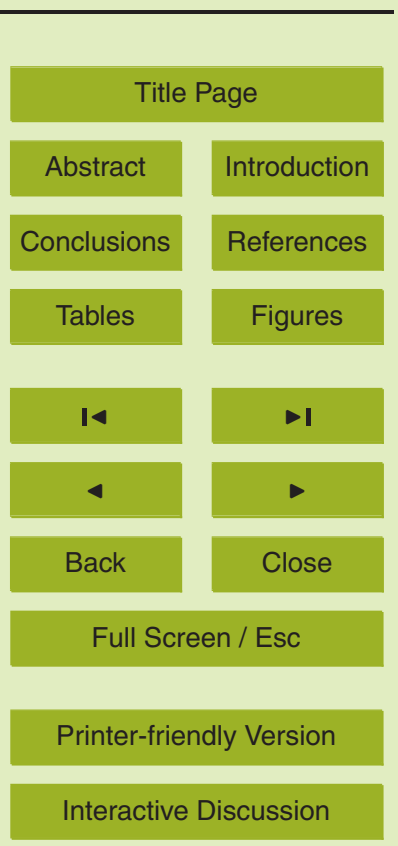


BGD

5, 1511-1543, 2008

\section{Albedo and sequestration in LULUCF projects}

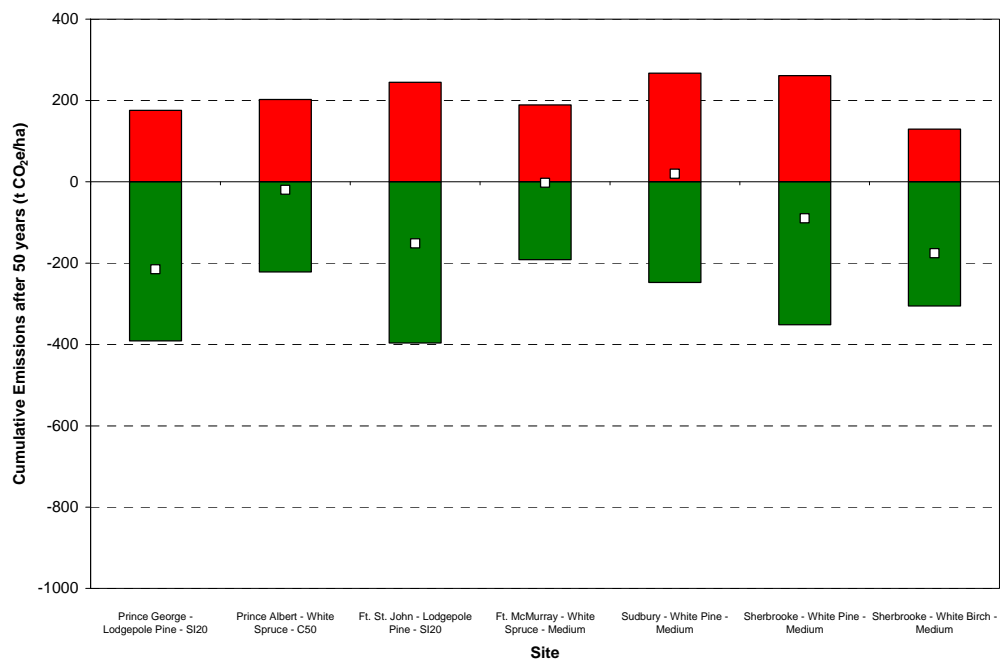

ISequestration

aAlbedo

$\square \mathrm{Ne}$

D. N. Bird et al.

Title Page

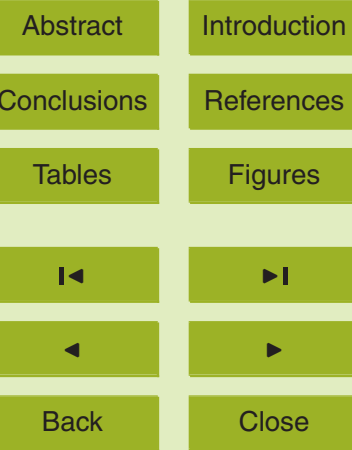

Full Screen / Esc

Printer-friendly Version

Interactive Discussion 
BGD

$5,1511-1543,2008$

Net Cumulative Emissions after 100 years

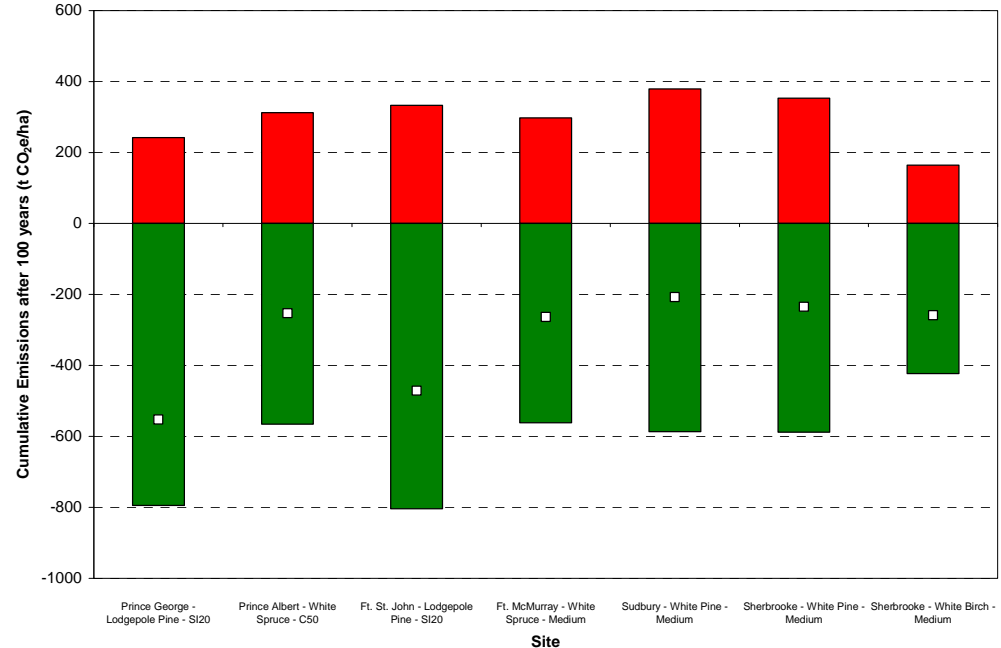

घAlbedo

口Net

\section{Albedo and} sequestration in LULUCF projects

D. N. Bird et al.

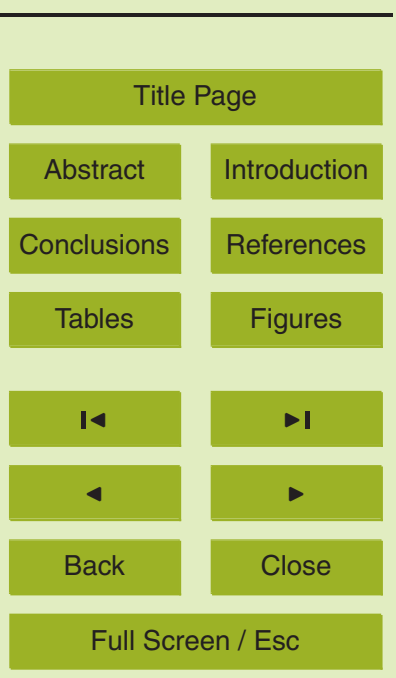

Printer-friendly Version

Interactive Discussion 